\title{
PEMANFAATAN OPEN EDUCATIONAL RESOURCES (OER) DALAM TUTORIAL ONLINE
}

\author{
Afriani \\ Universitas Terbuka \\ e-mail: afriani@ecampus.ut.ac.id
}

\begin{abstract}
This article aims to present the results of analysis of the problems associated with the use of Open Educational Resources (OER) in the online tutorial at the Department of English Literature at Universitas Terbuka (UT). The method used is descriptive method to describe the actual situation in the presentation of the data and evaluate them to find answers to the research questions. The collected data have been described and studied in depth in order to obtain a greater understanding of research purposes. The research approach is a qualitative and quantitative approach. Merging the two approaches is the best way for each approach will be complementary. The data used is a questionnaire with closed questions and interviews. The findings indicate that OER contributes significantly in online tutorial and helps the participants to comprehend the material.
\end{abstract}

Keywords: Distance Learning, Open Educational Resources, online tutorials, translation

\section{PENDAHULUAN}

Pesatnya perkembangan teknologi saat ini berimbas pada peningkatan pembelajaran secara online. Salah satu sumber pembelajaran yang dapat diakses adalah Open Educational Resources (OER). Salah satu institusi penyelenggara layanan jarak jauh yang memanfaatkan OER adalah Univeristas Terbuka (UT). UT merupakan penyelenggara pendidikan tinggi terbuka dan jarak jauh. Istilah terbuka adalah tidak ada batasan usia, tahun ijazah, masa belajar, waktu registrasi, dan frekuensi mengikuti ujian. Makna jarak jauh berarti pembelajaran yang diselenggarakan di UT tidak dilakukan secara tatap muka, melainkan menggunakan media, baik media cetak (modul) maupun non cetak berupa audio/video, internet, dan web supplement. Tentu saja OER menjadi sesuatu yang penting digunakan di dalam layanan belajar yang diberikan oleh UT.

Salah satu layanan bantuan belajar yang diberikan UT adalah tutorial online (tuton) yang dapat diikuti oleh mahasiswa pada tiap semester. Tuton adalah layanan tutorial berbasis internet atau web-based tutorial (WBT), yang ditawarkan oleh UT dan diikuti oleh mahasiswa melalui jaringan internet. Di dalam penyelenggaraannya, selain memaparkan materi, tutor tuton dapat memberikan OER sebagai materi pengayaan di dalam tuton.

Artikel ini merupakan hasil penelitian yang bertujuan untuk memaparkan sejauh mana pemanfaatan OER di dalam tuton oleh mahasiswa. Diharapkan hasil penelitian ini diharapkan dapat memberikan gambaran pentingnya pemberian OER di dalam tuton sehingga berimbas kepada peningkatan jumlah partisipasi mahasiswa mengikuti tuton dan memberikan sumbangan pemikiran dalam memperkaya wawasan mengenai OER. 


\section{Open Educational Resources (OER)}

Kajian pustaka diambil dari kata kunci Open Educational Resources dan OER. Untuk hasil yang lebih kekinian, pencarian dibatasi dari tahun 2013 sampai dengan 2018. OER menyajikan media atau materi yang bersifat Creative Commons Licence yang bebas biaya dan secara umum dapat diakses secara online. Media atau materi yang diberikan dapat berupa kurikulum, objek pembelajaran, modul, blog, dan repositori dengan format termasuk teks, gambar, audio, video, simulasi interaktif, dan gem atau permainan (Deimann \& Farrow, 2015)

Sebelumnya McGreal (2013) juga mengatakan bahwa OER adalah bahan pembelajaran yang penting berpotensi untuk memfasilitasi perluasan belajar di seluruh dunia. Masih menurut McGreal (2013) bahwa bentuk OER tidak hanya berupa digital dan dapat juga berupa hardcopy sehingga dapat digunakan pada pembelajaran tatap muka atau jarak jauh. Bedanya hanyalah, jika yang berupa hardcopy sifatnya berbayar, yang digital sifatnya gratis. Istilah OER pertama kali digunakan pada tahun 2002 oleh UNESCO pada "Forum on the Impact of Open Courseware for Higher Education in Developing Countries," yang disponsori oleh The William and Flora Hewlett Foundation. Istilah itu dikenal sebagai suatu istilah "Penyediaan sumber daya pendidikan yang terbuka, diaktifkan oleh teknologi informasi dan komunikasi, untuk konsultasi, penggunaan dan adaptasi oleh komunitas pengguna untuk tujuan non-komersial" (UNESCO 2002, p. 24) (Friesen, 2013).

Ally dan Samaka (2013) lebih fokus kepada penggunaan OER di daerah dan mereka mengatakan bahwa OER dapat diakses tdiak hanya di kota-kota besar tetapi juga di daerah pelosok dengan hanya menggunakan ponsel. Downes (2013) menambahkan OER lebih banyak diproduksi dan dibuat di dalam The Massive Open Online Course (MOOC) dan menyarankan penggunaan OER di dalam MOOC sebagai sarana untuk komunikasi antar peserta kursus.

Untuk memperkaya teori, pencarian ditambah dari database google.com, repository Perpustakaan Universitas Terbuka, jurnal The ASEAN Journal of Open and Distance Learning (AJODL). Daryono dan Belawati (2013) mengkaji tentang OER secara luas di Indonesia. Penggunaan OER di tingkat universitas masih perlu ditingkatkan baik dari segi hukum maupun insfrastruktur yang mengaturnya.

Dari pemaparan teori di atas dapat dikatakan tidak ada yang sangat relevan dengan penelitian ini, sehingga diharapkan hasil penelitian ini memberikan gambaran bagaimana pemanfaatan OER di dalam tutorial online atau online learning secara umum.

\section{Tutorial Online (Tuton)}

Tuton dilakukan oleh tutor online baik yang ada di UT Pusat maupun di UPBJJ-UT dengan memberikan delapan kali inisiasi termasuk di dalamnya memberikan tiga tugas kepada peserta tutorial selama periode tutorial (Puspitasari, 2002). Tujuan dari penyelenggaraan tuton adalah (1) mengoptimalkan pemanfaatan jaringan internet untuk memberikan layanan bantuan belajar kepada mahasiswa, (2) memungkinkan proses pembelajaran jarak jauh di desain lebih komunikatif dan interaktif Link, dan (3) memberi alternatif pilihan bagi mahasiswa yang memiliki akses terhadap jaringan internet untuk memperoleh layanan bantuan belajar secara optimal (Universitas Terbuka, 2004).

Tutor tuton di UT yang menjadi penanggung jawab tuton sangat berperan dalam upaya pengelolaan dan pengembangan tuton. Salah satu cara yang dapat dilakukan oleh tutor selain menyajikan materi adalah memperkaya tuton dengan Open Educational Resources (OER). 
Pemberian OER di dalam tuton sangat penting disamping sebagai pengayaan materi juga membuat tampilan tuton tidak monoton.

\section{METODE}

Subjek penelitian adalah mahasiswa aktif S1 Sastra Inggris bidang minat Penerjemahan yang mengambil tuton pada semester 1 tahun 2016 yang berada di tiga Unit Program Belajar Jarak Jauh (UPBJJ) UT yang berada di kota besar dan memiliki akses internet yang mumpuni. UPBJJ adalah sebagai tempat mahasiswa untuk melakukan kegiatan administratif akademik dan kegiatan akademik yang berada di daerah. Terdapat tiga UPBJJ-UT terbesar, yakni memiliki sebaran mahasiswa prodi Sastra Inggris Bidang Minat Penerjemahan: (1) UPBJJ-UT Jakarta dengan jumlah mahasiswa sebanyak 764 mahasiswa, UPBJJ-UT Bogor dengan jumlah mahasiswa sebanyak 178 mahasiswa, dan UPBJJ-UT Yogyakarta sebanyak 155 mahasiswa. Total semua mahasiswa di tiga UPBJJ-UT itu adalah sebanyak 1.098 mahasiswa. Pada tuton semester 1 tahun 2016 terdata sebanyak 58 kelas tuton dengan jumlah peserta sebanyak 24.853 mahasiswa. Populasi penelitian ini adalah semua mahasiswa yang aktif pada tuton pada program studi Sastra Inggris bidang minat Penerjemahan yang menggunakan OER, yakni 11 mata kuliah. Semua mahasiswa aktif itu diberikan kuesioner. Kemudian, pengambilan sampling dilakukan secara purposive sampling sehingga diperoleh sebanyak 88 data. Selain melalui kuesioner, data juga diperoleh melalui wawancara yang menghasilkan sebanyak 21 data.

Metode penelitian yang digunakan adalah metode deskriptif untuk mendeskripsikan keadaan sebenarnya dalam penyajian data dan mengkajinya untuk mencari jawaban atas pertanyaan penelitian. Penelitian dengan metode deskriptif itu dipilih karena catatan penelitian ditekankan pada pemberian deskripsi kalimat yang rinci, lengkap, mendalam, yang menggambarkan situasi sebenarnya untuk mendukung penyajian data. Data yang telah dikumpulkan dideskripsikan dan dikaji secara mendalam agar diperoleh pemahaman yang lebih nyata terkait tujuan penelitian.

Pendekatan penelitian yang digunakan adalah pendekatan kualitatif dan kuantitatif. Menurut Condelly (2004) penggabungan dua pendekatan itu merupakan cara terbaik karena masing-masing pendekatan akan saling melengkapi. Mengingat pendekatan yang digunakan adalah mixed method, penggabungan pendekatan kualitatif dan kuantitaif, maka sumber data dalam penelitian ini adalah kuesioner dengan pertanyaan tertutup dan wawancara. Kuesioner dengan pertanyaan tertutup belum dapat menjawab semua permasalahan di dalam penelitian ini. Oleh karena itu dilakukan wawancara untuk mengetahui lebih mendalam mengenai permasalahan yang ada yang tidak dapat diungkapkan di dalam kuesioner dengan pertanyaan terbuka itu.

Data kuesioner yang sudah diperoleh kemudian dianalisis secara statistik deskriptif dengan menggunakan program SPSS 2014, sedangkan data hasil wawancara ditranskripsikan dan dianalisis melalui tiga tahap, yakni mereduksi atau merangkum data sehingga didapat data yang sesuai dengan scope penelitian, dilanjutkan dengan penyajian data sehingga diperoleh informasi yang tersusun yang memberi kemungkinan adanya penarikan kesimpulan, dan yang terakhir adalah kesimpulan atau verifikasi.

\section{HASIL DAN PEMBAHASAN}

Pemanfaatan OER yang diberikan melalui tuton dianalisis menjadi empat poin, yakni waktu pemberian OER, kemudahan mengunduh OER, OER membantu mahasiswa memahami materi tuton, dan pemanfaatan OER di dalam tuton. 


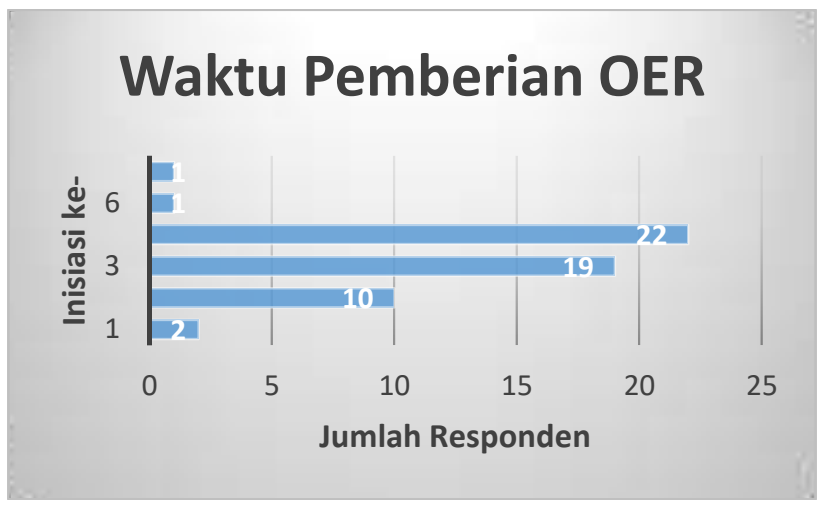

Grafik 1. Waktu pemberian OER

Berdasarkan Grafik 1, sebagian besar responden menganjurkan bahwa tutor sebaiknya memberikan OER pada materi tuton inisiasi ke-3 dan ke-4 atau inisiasi pada pertengahan periode tuton dengan alasan bahwa pada awal dan akhir inisiasi materi yang diberikan tidak begitu sulit dipahami. Di samping itu, ada juga responden yang menyatakan bahwa OER diperlukan pada setiap inisiasi dengan alasan bahwa OER akan memudahkan mahasiswa dalam memahami materi. Sebagian responden juga mengatakan bahwa sebaiknya OER hanya perlu diberikan pada materi yang dirasa sulit dipahami oleh mahasiswa. Berikut adalah pernyataan responden.

Saya kan kerja, jadi ngerasa penting ikut tuton ya sekalian belajar karena saya tidak maksimal baca modul...kadang itu....materi tuton susah juga dipahami tuh pada tengah-tengah tuton kayak inisiasi 3, 4, 5 atau tengahtengah lah....tapi ada video yang diberikan jd lumayan lah bisa mambantu.

Kalo awal tuton sih gampang, Cuma perkenalan jd belum sulit, kalo di akhir kan biasanya reviu saja, ada sih materi tapi gak susah, saya rasa begitu.

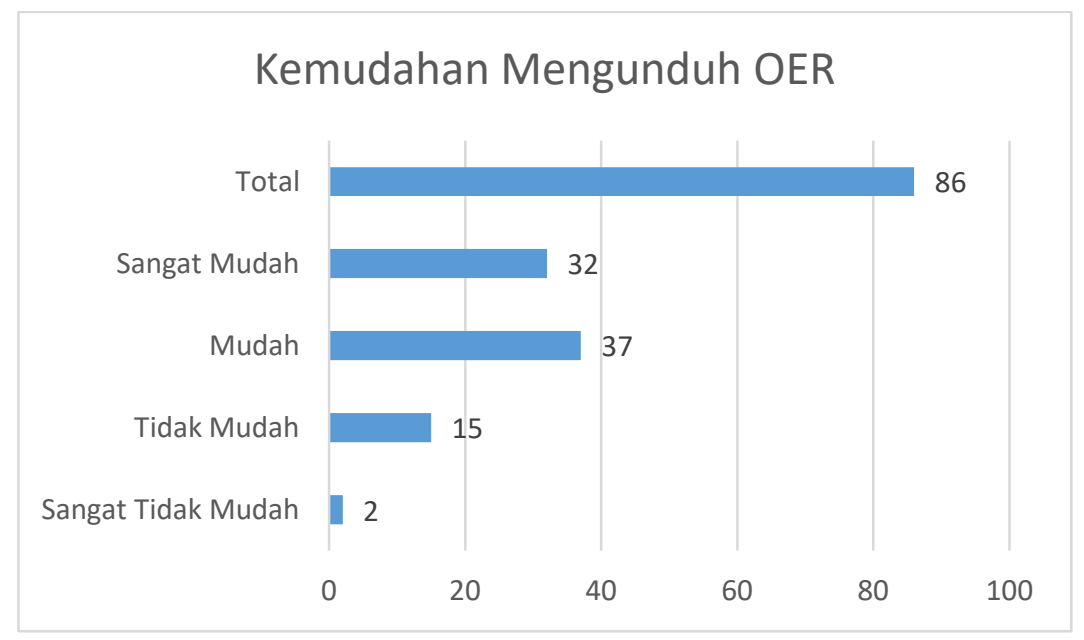

Grafik 2. Kemudahan mengunduh OER 
Dari Grafik 2 dapat diketahui bahwa sebagian besar mahasiswa mudah dan sangat mudah mengunduh atau mengakses OER di dalam tuton. Di samping itu, ada sebagian kecil yang menyatakan tidak mudah untuk mengunduh OER. Berikut adalah pernyataan mahasiswa yang menyatakan kemudahan dalam mengunduh OER.

Selama ini saya tidak ada kendala melihat video di tuton. Mungkin karena sinyalnya lagi baik ya, hehe

Oke oke aja tuh, ya emang sih pernah sekali kayaknya agak lama tapi bisa diakses, ya so far so good lah.

Dari pernyataan di atas dapat dikatakan bahwa responden hampir tidak tidak memiliki kendala untuk mengakses OER yang diberikan di dalam tuton.

\section{OER Membantu Mahasiswa Memahami Materi Tuton}

Pemberian OER di dalam tuton memang diharapkan dapat membantu mahasiswa memahami materi tuton yang sulit. Kontribusi OER di dalam tuton ditinjau dari dua segi, yakni kesulitan mahasiswa memahami materi tuton dan keberadaan OER di dalam tuton untuk membantu memahami materi tuton. Berikut adalah pemaparannya.

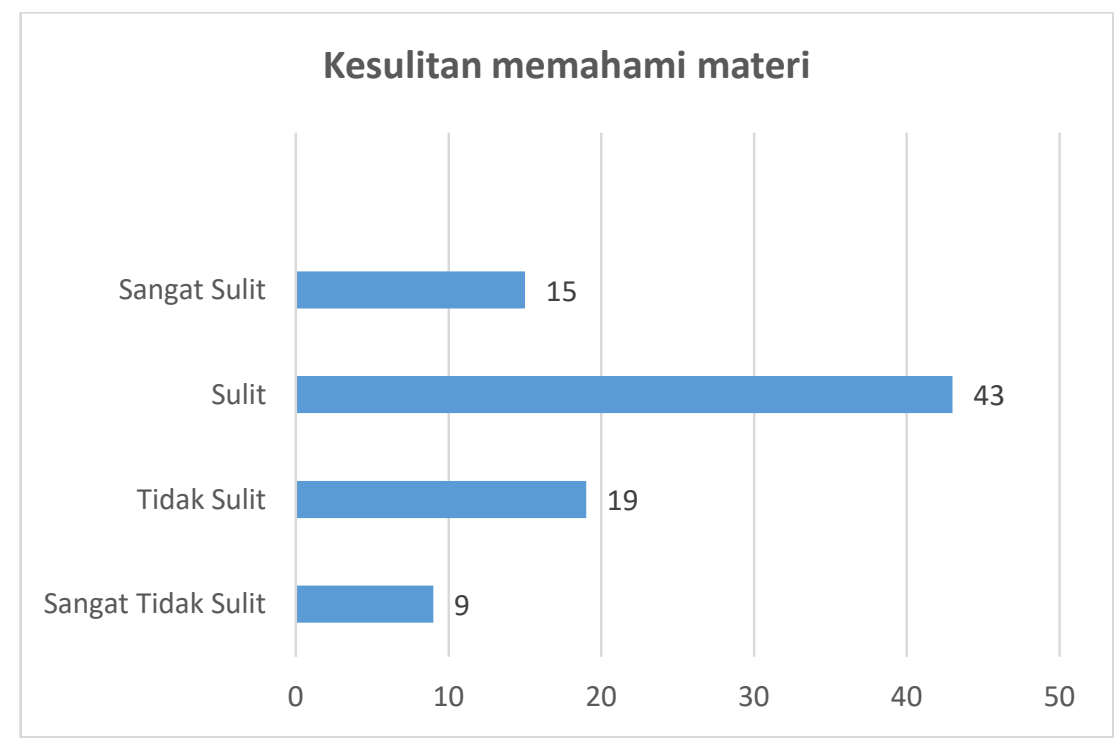

Grafik 3. Kesulitan memahami materi tuton

Dari Grafik 3, sebagian besar responden menyatakan bahwa mereka kesulitan dan sangat sulit memahami materi tuton. Hanya sebagian kecil responden yang menyatakan pemberian OER tidak sulit dan sangat tidak sulit untuk memahami materi tuton. Kesulitan memahami materi tuton diperkuat dengan pernyataan mahasiswa dari data wawancara berikut. 
Materi tuton kadang suka gak jelas...hehe, mau nanya teman juga sama bingungnya.

Saya kan ambil matakuliah teori penerjemahan, baru liat judulnya aja dah pusing...gimana ya..hehe

Dari pernyataan di atas dapat dikatakan bahwa tidak semua materi tuton mudah dipahami oleh mahasiswa. Mereka juga merasakan kesulitan untuk mencari teman untuk mendiskusikan materi yang sulit karena mahasiswa lain juga merasakan kesulitan yang sama.

\section{OER di dalam tuton untuk membantu memahami materi tuton}

Pemberian OER di dalam tuton sangat membantu mahasiswa untuk memahami materi tuton. Dari grafik di bawah terlihat bahwa sebagian besar menyatakan OER penting diberikan di dalam tuton dengan alasan selain modul atau bahan ajar cetak (BAC) yang dimiliki oleh mahasiswa, tuton merupakan layanan yang mudah mereka dapatkan. Hanya saja jika materi tuton sulit dipahami mahasiswa, maka OER merupakan sumber yang perlu untuk diakses oleh mahasiswa.

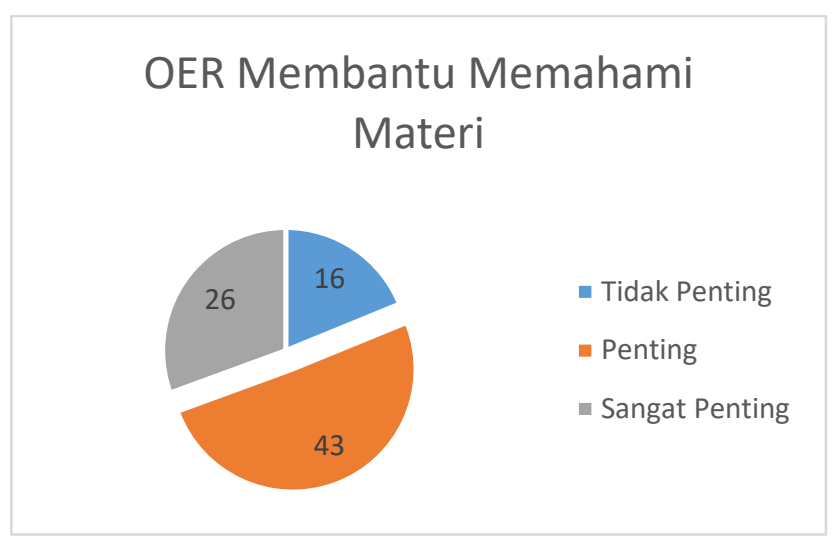
materi tuton.

Berikut adalah pernyataan responden tentang OER membantu mereka dalam memahami

Saya senang kalo ada slide show atau video di dalam tuton, gimana ya...kayaknya membantu banget buat saya.

Oh itu OER namanya, hehe saya baru tau. Tapi oke buat saya, kadang bosan baca materi dan gak mudeng, tapi video membantu kok.

Dari analisis di atas dapat disimpulkan bahwa OER sangat membantu mahasiswa memahami materi tuton. OER seharusnya di dalam tuton sehingga materi tuton lebih mudah dipahami oleh mahasiswa.

\section{Pemanfaatan OER di dalam tuton}

Bagian ini merupakan pembahan hasil analisis data yang dikaitkan dengan permasalahan penelitian, yakni pemanfaatan OER di dalam tuton oleh mahasiswa. Jika dilihat dari waktu pemberian OER di dalam tuton, OER lebih maksimal dimanfaatkan oleh mahasiswa jika diberikan pada inisiasi 
yang memuat materi yang lebih sulit seperti inisiasi atau minggu ketiga, keempat, kelima, keenam, dan ketujuh. Namun demikian, pemberian OER di dalam tuton juga diperlukan pada setiap inisiasi tuton.

OER dapat dimanfaatkan oleh mahasiswa untuk membantu memahami materi tuton. Tidak semua materi yang disajikan di dalam tuton dapat dicerna dengan mudah oleh mahasiswa sehingga pemberian OER di dalam tuton dapat membantu mahasiswa dalam memahami materi yang diberikan oleh tutor.

Dapat dikatakan, poin penting yang menjadi temuan adalah pemberian OER di dalam tuton dapat dimanfaatkan oleh mahasiswa terutama untuk memahami materi tuton yang sulit. Di samping menambahkan temuan dari penelitian sebelumnya yang menyatakan bahwa OER dapat diakses tidak hanya di kota-kota besar tetapi juga di pelosok dengan menggunakan ponsel (Ally dan Samaka, 2013), dan pemanfaatan OER juga tepat digunakan di dalam MOOC sebagai sarana untuk komunikasi antar peserta (Downes, 2013), OER juga dapat dimanfaatkan di dalam tuton mengingat sebaran mahasiswa UT tidak hanya di kota besar tetapi juga banyak di daerah kecil.

\section{SIMPULAN DAN SARAN}

Setelah menganalisis data yang berhubungan dengan pemanfaatan OER oleh mahasiswa, dapat disimpulkan bahwa pemanfaatan OER di dalam tuton dapat lebih maksimal pada pertengahan masa tuton atau pada pemberian materi yang dianggap sulit. Kemudian, OER juga mudah dimanfaatkan oleh mahasiswa. Di samping itu, pemberian OER di dalam tuton dapat meningkatkan dan membantu peserta tuton dalam memahami materi yang disajikan di dalam tuton. Dengan demikian dapat dikatakan penyediaan OER di dalam tuton dapat dimanfaatkan oleh mahasiswa untuk memahami materi yang diberikan di dalam tuton.

Peneliti juga menyarankan bahwa tampilan OER sebaiknya yang mudah diakses oleh mahasiswa dapat berbentuk tayangan powerpoin dan video. Selain itu, sebaiknya pemilihan OER yang berbahasa Inggris yang diberikan di dalam tuton disertai penjelasan dalam bahasa Indonesia sehingga memudahkan peserta tuton untuk memahami materi yang diberikan.

\section{REFERENSI}

Ally, Mohamed \& Samaka, Mohammed. (2013). Open education resources and mobile technology to narrow the learning divide, Vol. 14 No. 2.

http://www.irrodl.org/index.php/irrodl/article/view/1530

Condelly, L. (2004). Real World Research: Combining Qualitative and Quantitative Research for Adult ESL. Washington, DC. USA.

Daryono \& Belawati, Tian. (2013). Prospects and Challenges for Introducing Open Educational Resources in Indonesia. Dalam PERSPECTIVES ON OPEN AND DISTANCE LEARNING: Open Educational Resources: An Asian Perspective. https://oerknowledgecloud.org/sites/oerknowledgecloud.org/files/pub_PS_OER_Asia_web.pd $\underline{f}$

Deimann, Markus \& Farrow, Robert. (2015). Rethinking OER and their Use : Open Education as Bildung. FernUniversitaet in Hagen, Germany, 2The Open University UK http://oro.open.ac.uk/36572/1/Deimann\%20\%26\%20Farrow.pdf

Downes, Stephen, (2013). The Role of Open Educational Resources in Personal Learning. National Research Council of Canada. https://s3.amazonaws.com/academia.edu.documents/31833499/pub_PS_OER- 
IRP_web.pdf?AWSAccessKeyld=AKIAIWOWYYGZ2Y53UL3A\&Expires=1548304589\&Signa ture=E0\%2FwHVicl5UxiZMfELj2uH7|\%2FI0\%3D\&response-contentdisposition=inline\%3B\%20filename\%3DOpen_Educational_Resources_Innovation_Re.pdf\#p age $=233$.

Friesen, N. (2013). Realising the Open in Open Educational Resources: Practical Concerns and Solutions. Perspectives on Open and Distance Leraning: Open Educational Resources: Innovation, Research and Practice. Vancouver: Athabasca University.

Puspitasari, K.A. (2002). Layanan Bantuan Bagi Mahasiswa Universitas Terbuka. Buku: Pendidikan Terbuka dan Jarak Jauh, hal. 315-333. Jakarta: Universitas Terbuka.

McGreal, R. (2013). Open Educational Resources University: An Assessment and Credit for Students Initiative. Perspectives on Open and Distance Leraning: Open Educational Resources: Innovation, Research and Practice. Vancouver: Athabasca University.

Universitas Terbuka. (2004). Pedoman Penyelenggaraan Tutorial Online. Jakarta: Universitas Terbuka. 